Jeffrey E. Roberts, ${ }^{*}$ Bernard A. MacLeod MD FRCPC, $\dagger$ Raymond H. Hollands MD FRCSC $\ddagger$

\title{
Improved peribulbar anaesthesia with alkalinization and hyaluronidase
}

\begin{abstract}
A prospective double-blind randomized study was carried out to determine the effect of $\mathrm{pH}$ and the addition of hyaluronidase to a mixture of lidocaine and bupivacaine on the efficacy of peribulbar anaesthesia. One hundred patients were assigned to one of five groups. All groups received a solution of two parts bupivacaine $(0.75 \%)$ and one part lidocaine $(2 \%)$ (with 1:100,000 adrenaline) as the base components of their anaesthesia. Group 1 received only the bupivacaine-lidocaine mixture, $p H$ 3.9. Group 2 received a solution supplemented with hyaluronidase (ten units $\cdot \mathrm{ml}^{-1}$ ), $\mathrm{pH}$ of 5.1. Group 3 received the bupivacaine-lidocaine mixture alkalinized with sodium bicarbonate to a pH of 5.1, the same as solution 2. Group 4 received the mixture with hyaluronidase alkalinized to $p H$ of 6.7. Group 5 received the bupivacaine-lidocaine mixture alkalinized to a pH of 6.7. Efficacy of each block was graded according to the degree of residual movement 30 min following injection, as described by House et al. ${ }^{\prime}$ The solution containing hyaluronidase and $\mathrm{pH}$ adjusted to 6.7 was found to be the most effective $(P<0.025)$. The presence of hyaluronidase without alkalinization did not improve the efficacy of the mixture; and similarly, alkalinization in the absence of hyaluronidase was ineffective. These results reflected the $\mathrm{pH}$ - and temperaturedependent thermodynamic properties of local anaesthetics, and the $p H$-dependent activity of hyaluronidase.
\end{abstract}

\section{Key words}

ANAESTHETIC TECHNIQUES: regional, peribulbar; ANAESTHETICS, LOCAL: lidocaine, bupivacaine; ENZYMES: hyaluronidase.

From the Departments of *Pharmacology, $\uparrow$ Anaesthesia, †Ophthalmology, University of British Columbia.

Address correspondence to: Jeffrey E. Roberts, Department of Pharmacology and Therapeutics, University of British Columbia, 2176 Health Sciences Mall, Vancouver, B.C., V6T 1 Z3.

Accepted for publication 27th May, 1993.
Une étude randomisée et à double insu est réalisée dans le but de déterminer l'effet du $\mathrm{pH}$ et de l'ajout dhyaluronidase à un mélange de lidocaïne et de bupivacaïne sur l'efficacité de l'anesthésie péribulbaire. Cent patients sont répartis en cinq groupes. Tous les groupes reçoivent une solution de deux parties de bupivacaïne $(0,75 \%)$ et d'une partie de lidocaïne (2\%) adrénalinées à 1:100,000 comme agent de base. Le groupe I ne reçoit que le mélange bupivacaïne-lidocaïne à $p H 3$,9. Le groupe 2 reçoit la solution supplémentée d'hyaluronidase $\left(10 \mathrm{u} \cdot \mathrm{ml}^{-1}\right)$ à $p H 5,1$. Le groupe 3 reçoit le mélange bupivacaïne-lidocaïne alcalinisé au bicarbonate de soude pour porter le pH à 5,1 comme la solution 2. Le groupe 4 reçoit le mélange supplémenté dhyaluronidase alcalinisé au $\mathrm{pH}$ de 6.7. Le groupe 5 reçoit le mélange bupivacaïne-lidocaïne alcalinisé au pH 6,7. L'efficacité de chaque bloc est cotée selon le degré des mouvements résiduels 30 min après linjection, selon la méthode de House et al.' La solution contenant de l'hyaluronidase avec un $p H$ ajusté à 6.7 a été trouvée la plus efficace $(P<0,025)$. La présence d'hyaluronidase sans alcalinisation n'améliore pas l'efficacité du mélange et de la même façon, lalcalinisation sans hyaluronidase n'améliore pas l'efficacité du mélange. L'alcalinisation en absence d'hyaluronidase n'est pas efficace. Ces résultats reflètent les propriétés thermodynamiques dépendantes $d u$ pH et de la températures des anesthésiques locaux, et l'activité de l'hyaluronidase elle-même dependante du $\mathrm{pH}$.

Previous studies indicated that the solution of choice for peribulbar anaesthesia is a $2: 1$ mixture of $0.75 \%$ bupivacaine and $2 \%$ lidocaine with $1 / 100,000$ adrenaline, and 10 units $\cdot \mathrm{ml}^{-1}$ of hyaluronidase. ${ }^{1}$ Past studies have demonstrated that raising the $\mathrm{pH}$ of the local anaesthetic (LA) mixtures with hyaluronidase reduces the onset time for anaesthesia and increases the percentage of successful peribulbar blocks. ${ }^{2,3}$ Alkalinization has been demonstrated to increase the duration of other blocks, including sciatic, ${ }^{4}$ brachial plexus ${ }^{5}$ and epidural blocks, ${ }^{6}$ while other studies have found contradictory results. ${ }^{7}$ In experiments using isolated nerve preparations, alkalinization of local anaesthetic solutions increases the efficacy of blocks and affording a higher concentration of anaesthetic at the nerve. ${ }^{8-12}$ 
The efficacy of an anaesthetic solution can be increased by varying the $\mathrm{pH}$, quantity of anaesthetic or adding hyaluronidase. The concentrations and volumes of anaesthetic solutions are often dictated by the particular block. Many studies have demonstrated that hyaluronidase improves the efficacy of retrobulbar anaesthesia; however, all of these experiments were performed at a constant $\mathrm{pH}$. Zahl et al., ${ }^{2}$ demonstrated that upon alkalinization of a mixture of lidocaine, bupivacaine and hyaluronidase for peribulbar anaesthesia, the onset to akinesia and the requirement for supplemental peribulbar injections was reduced. Our aim was to investigate the relationship between $\mathrm{pH}$ and hyaluronidase by changing both of these variables independently. Lewis et al. ${ }^{13}$ found that there was no benefit to alkalinization, and that a plain bupivacaine solution $(0.75 \%)$ with hyaluronidase (14 units $\cdot \mathrm{ml}^{-1}$ ) was more effective. One important difference between our experiment and theirs was that we added hyaluronidase prior to alkalinization. Hyaluronidase is packed in a phosphate buffer; therefore, their $\mathrm{pH}$ readings for the plain bupivacaine solution were one $\mathrm{pH}$ unit higher than those published (i.e., changed from 5.3 to 6.3 following the addition of hyaluronidase). $\mathrm{A} \mathrm{pH}$ of 6.3 is within the optimal $\mathrm{pH}$ range for hyaluronidase activity; therefore, a high rate of success is to be expected. We also demonstrated that hyaluronidase plays an important role in the maintenance of anaesthetic solubility during the process of alkalinization, in which case a large proportion of the anaesthetic was present as inactive aggregates. At a temperature of $20^{\circ} \mathrm{C}$ and a $\mathrm{pH}$ of 6.7 this plain bupivacaine solution becomes cloudy with precipitates, whereas in the presence of hyaluronidase the solution remains clear.

Since hyaluronidase is associated with a low but appreciable incidence of potentially serious allergic reactions, ${ }^{14}$ it would be desirable to exclude hyaluronidase from the anaesthetic solution if the efficacy of the block is not compromised. Therefore, a secondary goal of this experiment was to determine if an alkalinized mixture without hyaluronidase could achieve an equal or greater percentage of successful peribulbar blocks than the solution containing hyaluronidase, where success is defined as complete paralysis of the extraocular musculature.

\section{Methods}

Authorization for the study was obtained from the University of British Columbia Clinical Screening Committee for Research. One hundred patients ( $44 \mathrm{male}$ and $66 \mathrm{fe}-$ male) scheduled for extraocular lens implant surgery at University Hospital UBC site, were randomly and blindly divided into five groups each of 20 patients, assigned to one of five experimental solutions. Patients with a history of local anaesthetic complications, or who were currently
}

taking anti-coagulants, were excluded from the experiment. The average ages of patients in groups 1 to 5 were $73 \pm 9.5,72 \pm 14,76 \pm 10,70 \pm 12$ and $67 \pm 14$ yr (SD), respectively. The percentage of females in each group were $63 \%, 50 \%, 60 \%, 55 \%$, and $80 \%$, respectively.

All solutions contained $10 \mathrm{ml}$ lidocaine hydrochloride, $2 \%$, with $1 / 100,000$ adrenaline, and $20 \mathrm{ml}$ bupivacaine hydrochloride, $0.75 \%$. Each of the five patient groups was respectively assigned one of the following five solutions. Solution $\mathrm{LB}_{\mathrm{pH} 3.9}$ contained only the bupivacainelidocaine mixture, $\mathrm{pH}$ 3.9. Solution $\mathrm{LBH}_{\mathrm{pHS} \text {.0 }}$ contained ten USP units $\cdot \mathrm{ml}^{-1}$ of hyaluronidase $(\mathrm{pH}$ 5.0). Solution $\mathrm{LB}_{\mathrm{pH} 5.0}$ contained the bupivacaine-lidocaine mixture adjusted to the same $\mathrm{pH}$ as $\mathrm{LBH}_{\mathrm{pH} 5.0}(\mathrm{pH} 5.0)$, with 0.03 $\pm 0.01 \mathrm{mEq}$ sodium bicarbonate. Solution $\mathrm{LBH}_{\mathrm{pH} 6.7} \mathrm{con}-$ tained ten units $\cdot \mathrm{ml}^{-1}$ hyaluronidase, adjusted to a $\mathrm{pH}$ of 6.7 with $0.99 \pm 0.01 \mathrm{mEq}$ sodium bicarbonate. Solution $\mathrm{LB}_{\mathrm{pH} 6.7}$ was adjusted $0.93 \pm 0.11 \mathrm{mEq}$ sodium bicarbonate. Since these anaesthetic mixtures precipitate near $\mathrm{pH} 7.0$, a pH of 6.7 was chosen as the maximum $\mathrm{pH}$ for the alkalinized solutions. In the event of failed blocks, solution $\mathrm{LBH}_{\mathrm{pH} 6.7}$ was used for supplemental injections.

Two injections, both an inferior and superior, were performed in each patient using a 11/4 inch, 27-gauge needle. The inferior injection was positioned at the junction of the outer one-third and middle one-third of the inferior orbital margin. Initially the needle was directed rostrally to the bony margin and then superomedially to a depth of $1 \frac{1}{4}$ inches, but not into the retrobulbar space. The total injected volume was $8 \mathrm{ml}, 5 \mathrm{ml}$ was given infraorbitally and $3 \mathrm{ml}$ supraorbitally. The superior injection was positioned half-way between the medial canthus and the supraorbital notch, adjacent to the superior orbital margin. Initially the needle was directed rostrally to a depth of $1 \mathrm{~cm}$, then horizontally an additional $1 \mathrm{~cm}$. A Honan intraocular pressure reducer was applied to the eye, and inflated to approximately $30 \mathrm{mmHg}$. By applying pressure on the globe in this manner, intraocular pressure and bleeding are reduced and diffusion of the anaesthetic solution is enhanced. ${ }^{15-17}$ Blocks were assessed in a manner similar to that described by House et al. ${ }^{1}$ Efficacy in each quadrant was scored on a scale between 0 and 4 , with 0 representing complete paralysis; 1 , slight movement; 2 , moderate movement; 3 , slight immobility; and 4, full movement, with a total possible score of 16. Patients were assessed before and every $15 \mathrm{~min}$ after each injection. Once a complete block was achieved no further assessments were made; however, if complete akinesia was not achieved within $30 \mathrm{~min}$ the block was considered a failure, and a supplemental $5 \mathrm{ml}$ of the same solution was administered. All injections were performed by the same physician, and solution preparations and 
patient assessments by the same second experimenter. The $\mathrm{pH}$ measurement was made on a Beckman $\mathrm{pH} 170 \mathrm{pH}$ meter with an intrinsic error of $\pm 0.02 \mathrm{pH}$ units.

Mean $\mathrm{pH}$ value for $\mathrm{LBH}_{\mathrm{pH} 5.0}$ was compared statisti-

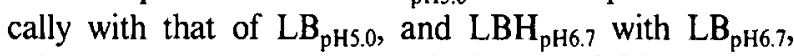
using a Students $t$ test. The incidence of failed blocks among groups were compared using the Fisher exact test, whereas the mean motor scores were compared using Kruskal-Wallis Multiple Comparison.

\section{Results}

Total motor score (TMS) for all 20 patients in each solution group (total possible score of 320 for no block and 0 for complete block), as well as the fraction of failed blocks and mean $\mathrm{pH}$ values for each solution, are presented in the Table. There was no difference between the mean $\mathrm{pH}$ value for $\mathrm{LBH}_{\mathrm{pH} 5.0}$ and $\mathrm{LB}_{\mathrm{pH} 5.0 \text {, or }}$ $\mathrm{LBH}_{\mathrm{pH} 6.7}$ and $\mathrm{LB}_{\mathrm{pH} 6.7}$. In order to obtain the desired $\mathrm{pH}$ values the volumes of bicarbonate added were adjusted throughout the course of the experiment, which accounted for the variability in mean volumes added.

Group $\mathrm{LBH}_{\mathrm{pH} 6.7}$ had a lower incidence of failed blocks, $(P<0.025)$, than the other groups. No differences were found in the incidence of failed blocks among the other groups. Similarly, group $\mathrm{LBH}_{\mathrm{pH} 6.7}$ had a lower mean motor score $(P<0.05)$ than the other groups, but no differences existed among the other groups.

\section{Discussion}

Solution " $\mathrm{LBH}_{\mathrm{pH} 5.0}$ " (lidocaine, bupivacaine and hyaluronidase; no bicarbonate), is the one most commonly used for peribulbar anaesthesia at our institution. The results indicate that the efficacy of this solution is either equal to or lower than a solution without hyaluronidase adjusted to the same $\mathrm{pH}$ (solution $\mathrm{LB}_{\mathrm{pH} 5.0}$ ). The optimal $\mathrm{pH}$ for this hyaluronidase is between 6.6 and 7.2, and the $\mathrm{pH}$ limits for activity are 6.4 and 7.4 (Wyeth Ltd., Toronto, Canada). At a pH of 5.0 the enzyme is inactive, or has a reduced activity than at physiological $\mathrm{pH}$. Since the volume of injectate is normally about half the volume of the periocular space, the peribulbar injection initially compartmentalizes upon injection. For this reason endogenous buffering systems would be slow to neutralize the acidic conditions presented by the unalkalized solutions and hyaluronidase in solution $\mathrm{LBH}_{\mathrm{pH} 5.0}$ is inactive for several minutes following the injection. Therefore, if the anaesthetic mixture is not alkalinized to a $\mathrm{pH}$ within the range 6.4-7.4 then hyaluronidase is not enzymatically active and can be excluded from the anaesthetic solution, so avoiding complications which may be associated with its use.

There was no increase in the efficacy of the block after alkalinization of the lidocaine-bupivacaine mixture. This
TABLE Peribulbar block assessment for each solution group at $30 \mathrm{~min}$

\begin{tabular}{lccc}
\hline Solution & $p H( \pm S D)$ & $T M S$ & Failed blocks \\
\hline $\mathrm{LB}_{\mathrm{pH} 3.9}$ & $3.87 \pm 0.31$ & $53 / 320$ & $11 / 20$ \\
$\mathrm{LBH}_{\mathrm{pH} 5.0}$ & $5.06 \pm 0.16$ & $40 / 320$ & $11 / 20$ \\
$\mathrm{LB}_{\mathrm{pH} 5.0}$ & $4.88 \pm 0.44$ & $36 / 320$ & $9 / 20$ \\
$\mathrm{LBH}_{\mathrm{pH} 6.7}$ & $6.66 \pm 0.30$ & $4 / 320^{*}$ & $2 / 20^{*}$ \\
$\mathrm{LB}_{\mathrm{pH} 6.7}$ & $6.70 \pm 0.10$ & $56 / 320$ & $11 / 20$ \\
\hline
\end{tabular}

$\mathrm{LB}_{\mathrm{pH} 3.9}=$ lidocaine + bupivacaine.

$\mathrm{LBH}_{\mathrm{pH} 5.0}=$ lidocaine + bupivacaine + hyaluronidase.

$\mathrm{LB}_{\mathrm{pH} 5.0}=$ lidocaine + bupivacaine, adjusted to $\mathrm{pH} 5.0$.

$\mathrm{LBH}_{\mathrm{pH} 6.7}=$ lidocaine + bupivacaine + hyaluronidase, adjusted to $\mathrm{pH} 6.7$.

$\mathrm{LB}_{\mathrm{pH} 6.7}=$ lidocaine + bupivacaine, $\mathrm{pH}$ adjusted to 6.7 .

$* P<0.05$ versus other groups.

result contradicts the basic pharmacokinetic theories of local anaesthetic actions. An explanation for this result relates to the temperature- and $\mathrm{pH}$-dependence of local anaesthetic solubility. ${ }^{18-20}$ Local anaesthetics are weak bases, and according to thermodynamic principles for weak bases, increases in temperature and $\mathrm{pH}$ produce an equilibrium shift in favour of the less soluble neutral species. At room temperature and at $\mathrm{pH}$ of 6.7 the bupivacaine-lidocaine mixture was close to threshold for precipitation; if the solution was either alkalanized further, or heated, precipitation would occur. It was determined that precipitation of the two alkalinized solutions, $\mathrm{LB}_{\mathrm{pH} 6.7}$ and $\mathrm{LBH}_{\mathrm{pH} 6.7}$, would have occurred at temperatures close to $30^{\circ} \mathrm{C}$ and $34^{\circ} \mathrm{C}$ respectively. Since the injectate is initially compartmentalized, heating by the surrounding tissue may result in higher concentrations of the neutral species of the local anaesthetic and subsequent precipitation of these alkalinized solutions within the orbit. Precipitated local anaesthetic is poorly absorbed and consequently has a greatly reduced efficacy. Hyaluronidase could counteract this problem by two mechanisms. Proteins reduce the rate of crystal formation by binding growing crystals to their surface. ${ }^{21}$ In this way hyaluronidase may have prevented precipitation within the orbit, as indicated by the $4^{\circ} \mathrm{C}$ increase in the temperature of precipitation with its addition. A second possibility is that the combination of enhanced hyaluronidase activity and anaesthetic lipophilicity may prevent compartmentalization and subsequent precipitation, by shortening absorption time.

By our criteria, every solution except for $\mathrm{LBH}_{\mathrm{pH} 6.7}$, had a failure rate of close to $50 \%$. Many physiciaris are content with small amounts of residual movement and may have accepted many of these failed blocks as complete. However, it is our opinion that complete akinesia is required before surgery can proceed safely. Supplemental injections present an added risk of complications, but 
with the use of a solution as efficacious as $\mathrm{LBH}_{\mathrm{pH} 6.7}$, there is rarely a need for additional anaesthesia under the most scrupulous conditions. All biases accepted, this scoring system still provided a valid means of qualitatively comparing the efficacies of these solutions.

It was shown that hyaluronidase can be used more efficiently in peribulbar anaesthesia if the anaesthetic solution is alkalinized to near physiological $\mathrm{pH}$. Hyaluronidase may also counteract local anaesthetic solubility problems that occur in these alkalinized solutions. If hyaluronidase is to be used then the anaesthetic mixture should be alkalinized to a $\mathrm{pH}$ of at least 6.4 . If the peribulbar injection is not alkalinized, then it seems reasonable to exclude hyaluronidase, avoiding risks associated with its use.

\section{References}

1 House PH, Hollands RH, Schulzer M. Choice of anaesthetic agents for peribulbar anethesia. J Cataract Refract Surg 1991; 17: 80-3.

2 Zahl K, Jordan A, McGroarty J, Sorensen B, Gotta AW. Peribulbar anesthesia. Effect of bicarbonate on mixtures of lidocaine, bupivacaine, and hyaluronidase with or without epinephrine. Ophthalmology 1991; 98: 239-42.

3 Zahl K, Jordan A, McGroarty J, Gotta AW. pH-adjusted bupivacaine and hyaluronidase for peribulbar block. Anesthesiology 1990; 72: 230-2.

4 McMorland GH, Douglas MJ, Jeffrey WK, et al. Effect of $\mathrm{pH}$-adjustment of bupivacaine on onset and duration of epidural analgesia in parturients. Can Anaesth Soc J 1986; 33: 537-41.

5 Coventry DM, Todd JG. Alkalinization of bupivacaine for sciatic nerve blockade. Anaesthesia 1989; 44: 467-70.

6 Hilgier M. Alkalinization of bupivacaine for brachial plexus block. Reg Aesth 1985; 10: 59-61.

7 Bedder MD, Kozody R, Craig DB. Comparison of bupivacaine and alkalinized bupivacaine in brachial plexus anesthesia. Anesth Analg 1987; 47: 48-52.

8 Chernoff DM, Strichartz GR. Kinetics of local anesthetic inhibition of neuronal sodium currents. $\mathrm{pH}$ and hydrophobicity dependence. Biophys J 1990; 58: 69-81.

9 Chernoff $D M$. Kinetic analysis of phasic inhibition of neuronal sodium currents by lidocaine and bupivacaine. Biophys J 1990; 58: 53-68.

10 Rosenberg $P H$, Heavner JE. Temperature-dependant nerve-blocking action of lidocaine and halothane. Acta Anaesthesiol Scand 1980; 24: 314-20.

11 Bradley DJ, Richards $C D$. Temperature-dependence of the action of nerve blocking agents and its relationship to membrane-buffer partition coefficients: thermodynamic implications for the site of action of local anaesthetics. $\mathrm{Br} \mathbf{J}$ Pharmacol 1984; 81: 161-7.

12 Catchlove RFH. The influence of $\mathrm{CO}_{2}$ and $\mathrm{pH}$ on local anesthetic action. J Pharmacol Exp Ther 1972; 181: 298-309.

13 Lewis P. Hamilton RC, Loken RG, Maltby JR, Strunin L. Comparison of plain with $\mathrm{pH}$-adjusted bupivacaine with hyaluronidase for peribulbar block. Can J Anaesth 1992; 39: 555-8.

14 Compendium of Pharmaceuticals and Specialties, Ottawa: Canadian Pharmaceutical Association, 1990; 1193.

15 Palay $D A$, Stulting $R D$. The effect of external ocular compression on intraocular pressure following retrobulbar anesthesia. Ophthalmic Surg 1990; 21: 503-7.

16 Ropo A, Ruusuvaara, Paloheimo M, Mauhuksela E-L, Nikki $P$. Effect of ocular compression (Autopressor) on intraocular pressure in periocular anaesthesia. Acta Ophthalmolol (Copenh) 1990; 68: 227-9.

17 Jay WM, Carter H, Williams B, Green K. Effect of applying the Honan intraocular pressure reducer before cataract surgery. Am J Ophthalmol 1985; 100: 523-7.

18 Strichartz GR, Sanchez V, Arthur GR, Chafetz R, Martin $D$. Fundamental properties of local anesthetics. II. Measured octanol:buffer partition coefficients and $\mathrm{pK}_{\mathrm{a}}$ values of clinically used drugs. Anesth Analg 1990; 71: 158-70.

19 Sanchez $V$, Sanchez V, Arthur GR, Strichartz GR. Fundamental properties of local anesthetics. I: The dependence of lidocaine's ionization and octanol:buffer partioning on solvent and temperature. Anesth Analg 1987; 66: 159-65.

20 Kamaya H, Hayes JJ Jr, Veda I. Dissociation constants of local anesthetics and their temperature dependence. Anesth Analg 1983; 62: 1025-30.

21 Nývlt J, Söhnel O, Matuchová M, Broul M. The effect of admixtures on the rate of crystal growth. In: The Kinetics of Industrial Crystallization, Amsterdam: Elsevier 1985; 189-90. 